\title{
Homing endonuclease and mobile intron in the novel hyperthermophilic archaeon Aeropyrum pernix isolated from marine hydrothermal vent
}

\author{
YOSHIHKKO SAKO, NORIMICHI NOMURA, YAYOI MORINAGA, AND ARTTSUNE UCHIDA \\ Division of Applied Biosciences, Graduate School of Agriculture, Kyoto University, Kyoto 606-8502, Japan \\ e-mail: sako@kais.kyoto-u.ac.jp (Y.Sako)
}

SUMMARY: Marine hyperthermophilic microorganisms are valuable resources for thermostable enzymes which are well suited for biotechnological applications. A novel DNA endonuclease I-Ape I was found from the hyperthermophilic archaeon Aeropyrum pernix and characterized. Of particular interest is that I-Ape I is encoded in the optional intron I $\alpha$ within the 16S rRNA gene. Probably, I-Ape I confer mobility to the host intron I $\alpha$, like group I intron homing endonucleases from eukaryotes and bacteriophages. Also, this rarecutting enzyme is a useful tool for genome mapping.

\section{KEY WORDS: archaea, hyperthermophile, ribosomal RNA gene, intron homing, DNA endonuclease}

\section{INTRODUCTION}

The myriad of microorganisms inhabiting marine hydrothermal ecosystems represent a vast repository of valuable thermostable enzymes for biotechnological applications. In the past two decades, a number of new hyperthermophiles have been isolated from deepsubmarine vents or coastal hot springs. ${ }^{1)}$ Among them, organisms with the highest growth temperatures (between 103 and $113^{\circ} \mathrm{C}$ ) are anaerobic members of the archaeal genera Methanopyrus, Pyrococcus, Pyrodictium, Pyrobaculum and Pyrolobus.

In previous studies, we succeeded in discovery of a strictly aerobic archaeon Aeropyrum pernix, which can grow at temperatures up to $100{ }^{\circ} \mathrm{C}{ }^{2 k}{ }^{3)}$ and have completed its whole genome sequencing (1.67 Mbp). ${ }^{4)}$ Our current project is to extract useful genetic resources from the dataset. DNA polymerases," a variety of proteases ${ }^{\circ}, \pi$ and restriction DNA endonucleases (Nomura $\mathrm{N}$ et al., unpubl. data, 2001) have so far been obtained from this organism.

During the work described above, we unexpectedly found an intron (I $\alpha$ ) interrupting the $16 \mathrm{~S}$ rRNA gene of this prokaryote. Most striking was that I $\alpha$ is "optional," i.e. is present in some but not all strains of the natural A. pernix populations. This observation suggest that $\mathrm{I} \alpha$ is a mobile genetic element which could propagate itself through the population. Here, we demonstrate that I $\alpha$ contains an open reading frame whose product (I-Ape I) can act as a site-specific DNA endonuclease. In addition, we propose a hypothetical invasion strategy of $\mathrm{I} \alpha$, in which I-Ape I could play a pivotal role as a trigger.

\section{MATERIALS AND METHODS}

Comparative sequence analysis of the 16S rRNA gene from natural isolates of $A$. pernix

The A. pernix strains used in this study, OH1, TB1 and TB7, were isolated as described previously. ${ }^{2)}$ Nearcomplete length of the 16S rRNA genes were amplified by ploymerase chain reaction (PCR) with the following primers: sense, 5'- ACTCCGGTTGATCCTGCCGGA and antisense, 5'- AGGTGATCCAGCCGCAGGTT. The resulting PCR product were cloned into PCR2.1 vector (Invitrogen). DNA sequencing was performed by the dideoxy-chain termination method on both strands of overlapping fragments.

Overexpression and purification of the intron I $\alpha$ encoded protein, I-Ape I

To overexpress the presumptive I-Ape I coding sequence independently of the rest of the 16S rRNA gene of A. pernix $\mathrm{K} 1$, codons 1 to 222 (according to the numbering in ref. 8) were inserted into a bacterial expression vector, as follows. To place an initiator methionine codon (ATG) and an Nde I site at the $5^{\prime}$ end of the I-Ape I coding segment, two oligonucleotide primers (sense, 5'- ACAT ATGAATGGTTGTG ATA TA and antisense, 5'- GGATC CTTAGCTGGGCCCG GGGAG -3') and A. pernix K1 chromosomal DNA as a template, a corresponding double-stranded DNA fragment was generated by PCR. One end of this PCR product has the sequence corresponding to the carboxyterminal end of the presumptive I-Ape I polypeptide followed immediately thereafter by a translational stop codon and an Bam HI site. Therefore, a 677-bp Nde IBam HI fragment of the PCR product that contains this region was subcloned into pET-15b to yield pHAI-01. Nucleotide sequence analysis confirmed that the 
inserted segment did not contain any unwanted PCRgenerated mutations.

Overexpression of I-Ape I was obtained by transforming pHAI-01 into $E$. coli strain BL21 (DE3)pLysS. A culture (6 liter) of transformed BL21 (DE3) pLysS cells was grown at $37{ }^{\circ} \mathrm{C}$ in LB broth $(1 \%$ Bacto-tryptone, $0.5 \%$ Bacto-yeast extract, $0.5 \% \mathrm{NaCl}, 1$ $\mathrm{mM} \mathrm{NaOH}$ ) supplemented with $50 \mu \mathrm{g} / \mathrm{ml}$ ampicillin to an $\mathrm{OD}_{600}=0.4$. Induction of the T7 RNA polymerase, and subsequently the I-Ape I gene under control of the T7 RNA polymerase-dependent phage promoter, was achieved by the addition of isopropyl-1-thio- $\beta-D-$ galacto- pyranoside (IPTG) to a concentration of 1.0 $\mathrm{mM}$ followed by further growth for $6 \mathrm{~h}$ at $37^{\circ} \mathrm{C}$. The culture was then chilled on ice, and the cells $(15 \mathrm{~g}$, wet weight) were harvested by centrifugation at $4{ }^{\circ} \mathrm{C}$. Unless otherwise stated, all subsequent operations were performed at $4{ }^{\circ} \mathrm{C}$. The cell pellet was washed and resuspended in 1.5 volumes of buffer A [50 mM Tris$\mathrm{HCl}(\mathrm{pH} 8.0), 0.1 \mathrm{mM}$ EDTA, $10 \%$ (v/v) glycerol, 0.5 $\mathrm{mM}$ dithiothreitol] containing $0.2 \mathrm{M} \mathrm{NaCl}$. The cell suspension was sonically irradiated with cooling on ice. The crude lysate was subjected to centrifugation for 20 $\min$ at $20,000 \times \mathrm{g}$ to remove unbroken cells and cellular debris. The resulting supernatant fraction was heated at $60{ }^{\circ} \mathrm{C}$ for $30 \mathrm{~min}$, and the thermal denatured proteins were removed by the sedimentation at $20,000 \times \mathrm{g}$ for 20 min. The supernatant solution was adjusted slowly to a final concentration of ammonium sulfate at $20 \%$ of saturation by the addition of a sufficient amount of the solid salt with stirring over $30 \mathrm{~min}$ on ice before centrifugation for $20 \mathrm{~min}$ at $20,000 \times \mathrm{g}$. Ammonium sulfate was then added to the supernatant to a final concentration of $50 \%$. After incubation on ice and centrifugation, the pellet was dissolved in $20 \mathrm{ml}$ of buffer A containing $0.2 \mathrm{M} \mathrm{NaCl}$, and dialyzed extensively against the same buffer twice. The dialysate was subjected to cation exchange chromatography (HiTrap SP; Amersham Pharmacia) followed by affinity chromatography (HiTrap Heparin; Amersham Phearmacia) and gel filtration chromatography (Superdex 75; Amersham Pharmacia). Fractions (1 ml each) were collected and assayed for endonuclease activity. Active fractions containing the bulk of the IApe I activity were pooled, and aliquots were stored at $20^{\circ} \mathrm{C}$. The purity of the recombinant I-Ape I protein in each fraction was verified by SDS-PAGE.

\section{Cleavage assay}

The partial portion of the 16S rRNA gene from $A$. pernix strain $\mathrm{OH} 1$ (position 6 to 1290 according to the E. coli numbering system) was amplified by PCR and cloned into pCR2.1 vector to construct a plasmid
pO2A2. Target DNA (0.5 $\mu \mathrm{g}$ of Eco RI-linearized pO2A2 plasmid; Fig.1) was incubated with $0.5 \mu \mathrm{g}$ of the purified I-Ape I protein in a total volume of $10 \mu \mathrm{l}$ containing $10 \mathrm{mM}$ Tris- $\mathrm{HCl}$ ( $\mathrm{pH} 7.5$ ), $10 \mathrm{mM} \mathrm{MgCl}_{2}$, $1 \mathrm{mM}$ dithiothreitol, and $50 \mathrm{mM} \mathrm{NaCl}$ at $90{ }^{\circ} \mathrm{C}$ for 30 min. During the incubation, the mixture was overlaid with $25 \mu \mathrm{l}$ of mineral oil. The reactions were stopped on ice with $2 \mu \mathrm{l}$ of dye mixture $[0.25 \%(\mathrm{w} / \mathrm{v})$ bromphenol blue, $0.25 \%(\mathrm{w} / \mathrm{v})$ xylene cyanol FF, $1 \mathrm{mM}$ EDTA, 30\% (v/v) glycerol]. Cleavage products were separated by electrophoresis in $1.5 \%$ agarose gels and visualized by staining with ethidium bromide.

\section{RESULTS}

\section{Polymorphic occurrence of optional introns in the $16 S$ rRNA genes of natural populations of $A$. pernix}

The sequence analysis of the single rRNA operon in the three A. pernix isolates, OH1, TB1 and TB7, showed polymorphism in intron insertion (Fig.1). The 16S rRNA gene of OH1 was intron-free. The 16S rRNA gene of TB1 possessed the following two introns: $\mathrm{I} \delta$ (62 bp after position 908 according to the Escherichia coli numbering of the $16 \mathrm{~S}$ rRNA) and I $\varepsilon$ (122 bp after position 1068 of the 16S rRNA). The introns in the $16 \mathrm{~S}$ rRNA gene of TB7 were identical to those of TB1. Striking was that $I \delta$ was inserted into a position which coincided with the I $\alpha$ in the 16S rRNA gene of K1. Despite a remarkable difference in size among I $\alpha(699$ bp) and $I \delta$ (62 bp), they shared similar terminal sequences, implying that these two introns derive from the same origin. The gap in the internal region could be attributed to a deletion. Direct sequencing of the mature $16 \mathrm{~S}$ and $23 \mathrm{~S}$ rRNAs confirmed that all of the newly found introns were spliced out of the RNAs (data not shown). The RNA sequences of I $\delta$ and I $\varepsilon$ at the exonintron junctions could be folded into a secondary structure with the well-established features of the 'bulgehelix-bulge (BHB)' core structure, 3-base loops on opposite strands separated by a 4-bp helix, of archaeal introns.

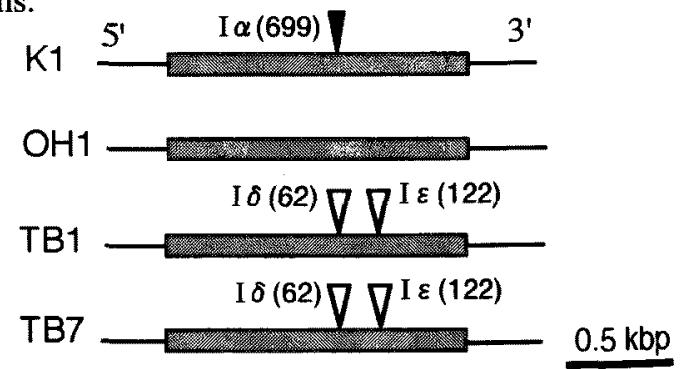

Fig. 1 Intron occurrence in the 16S rRNA gene of the A. pernix isolates. Filled and open triangles indicate ORFpossessing and ORF-less introns, respectively. Numbers in parenteses denote the intron length (in bp). 


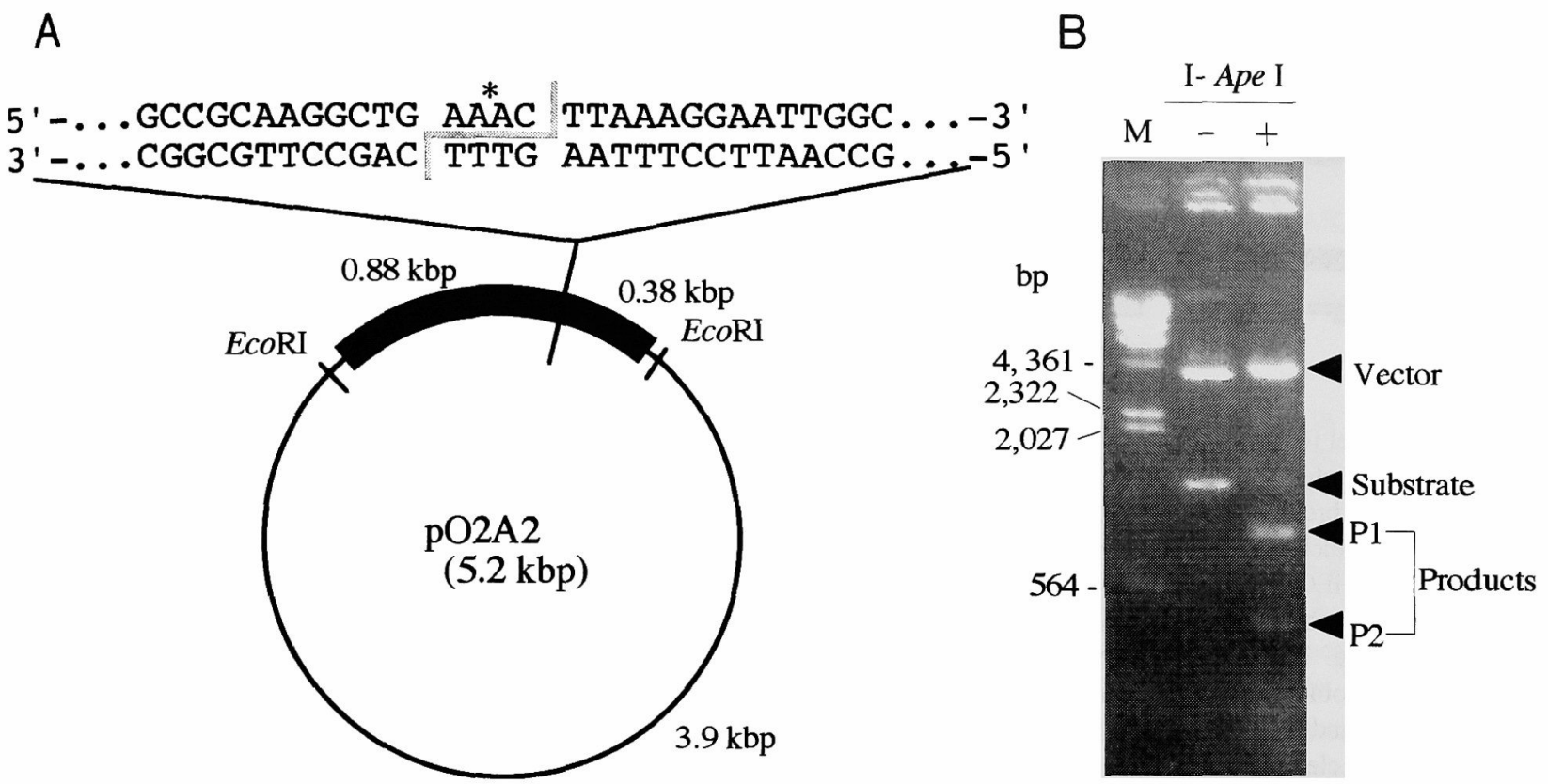

Fig. 2 DNA substrate and assay for recombinant I-Ape I activity. (A) Schematic representation of plasmid pO2A2. The unique EcoRI sites in the vector (solid circular line) and the DNA fragment containing intronless 16S rRNA gene that was inserted (closed arc) are indicated. The nucleotide sequence of the I-Ape I recognition/cleavage site, the staggered double-stranded break generated by I-Ape I reaction, and the predicted sizes of the two DNA fragments produced by I-Ape I cleavage from plasmid that was linearized by digestion with $E c o$ RI are also shown. I $\alpha$ insertion site is indicated by an asterisk. (B) Substrate DNA (pO2A2 linearized with EcoRI; $0.5 \mu \mathrm{g}$ ) was incubated for 30 min at $90^{\circ} \mathrm{C}$ in the absence $(-)$ or in the presence $(+)$ of $0.5 \mu \mathrm{g}$ of purified recombinant I-Ape I from E. coli. M, $\lambda$ Hind III.

\section{I-Ape I cleaves cognate intronless alleles in the vicinity of the $I \alpha$ insertion site}

The recombinant I-Ape I overexpressed in $E$. coli cells were tested in cleavage assays with the intronless $16 \mathrm{~S}$ rRNA gene form A. pernix $\mathrm{OH} 1$ as the DNA substrate. It showed high levels of cleavage activity (Fig. 2). Consistent with the hyperthermophilc nature of $A$. pernix, which grow optimally at 90 to $95^{\circ} \mathrm{C}$, I-Ape I was thermostable. The enzyme required $\mathrm{Mg}^{2+}$, was virtually inactive at temperatures up to $37{ }^{\circ} \mathrm{C}$, reached peak activity in the 85 to $90{ }^{\circ} \mathrm{C}$ range, and lost activity at higher temperatures (data not shown). It is unclear whether loss of activity above $90{ }^{\circ} \mathrm{C}$ reflects denaturation of the enzyme and/ or the substrate DNA.

The single cleavage site, which was observed exclusively for the intronless and not the introncontaining allele, was mapped by bidirectional primer extension analysis (data not shown). The cleavages on the two strands generated 4-nt 3' overhangs, which overlap the site at which the intron is inserted in the intron-containing allele (Fig. 2). I- Ape I appears to have an asymmetric recognition sequence.

\section{DISCUSSION}

The intron I $\alpha$ contain an open reading frame (ORF), and the following circumstantial evidences suggest that it is expressed in vivo : (i) only one ORF is possible for the intron, (ii) putative ribosome-binding sites, GGGAGGG, complementary to the 3' end of mature $16 \mathrm{~S}$ rRNA occur 10 to $15 \mathrm{nt}$ upstream of the start codons, (iii) free intronic RNA I $\alpha$ which could function as mRNA are stably accumulated in the cells, although their relative quantity could fluctuate in dependence on the physiological conditions. ${ }^{8}$ Comparative sequence analyses against DDBJ, EMBL, GenBank nucleotide sequence databases and SWISS-PROT, PIR protein sequence databases reveal no genes or proteins with any overall similarity. However, a search made with the sequence, ${ }^{128} \mathrm{VKGFVDAEG}^{136}$ in I $\alpha$ ORF revealed a similar motif (LAGLIDADG) characteristic of proteins encoded by many mobile group I introns from eukaryotes and bacteriophages." In Saccharomyces cerevisiae, the LAGLIDADG protein encoded by the intronic ORF of the mitochondrial 21S rRNA gene possesses endonuclease activity and causes a sitespecific double strand break of intronless variants of the 


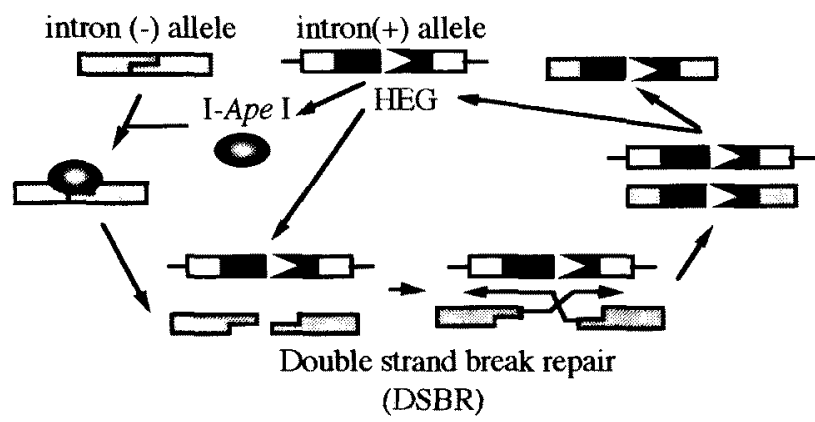

Fig. 3 Amodel for intron mobility. Intron mobility or homing is initiated and targeted by a site-specific DNA double strand break made in an intron-less allele by homing endonuclease I-Ape I encoded by the mobile intron ORF (HEG) . Double strand break repair (DSBR) transfers the mobile intron containing HEG to cleaved recipient allele. Resolution generates two alleles that contain the mobile intron. Intron insertion disrupts the homing site, and renders intron (+) alleles resistant to endonuclease cleavage.

gene, promoting efficient conversion to the introncontaining form. ${ }^{10)}$ In this context, we have developed the overexpression system of the I $\alpha$ ORF (I-Ape I) in $E$. coli and verified the intron-homing endonucleolytic activity.

Active I-Ape I is expressed from excised forms of the intron $\mathrm{I} \alpha$, suggesting that splicing is a prerequisite for synthesis of the active enzyme. Like the phage and eukaryotic enzymes, I-Ape I cleaves an intronless allele by making a staggered double-strand cut at an asynmmetric target site.

Although homing of the intron I $\alpha$ has not been demonstrated in A. pernix, mobility is implied by the existence of intron-containing and intronless variants (Fig. 1) and by cleave of the intronless allele by I-Ape I encoded in the intron-containing variant (Fig. 2). Coexistence of intron-containing and intronless alleles is implicit in homing, and intron mobility would therefore suggest that intercelluler genetic exchange takes place in the population of $A$. pernix. A model for intron mobility is given in Fig. 3. Probably, the ORFlacking introns, $\mathrm{I} \delta$ and $\mathrm{I} \varepsilon$, are deprived of mobility.

\section{ACKNOWLEDGMENTS}

This work was partially supported by Grant-in-Aid for Scientific Research from the Ministry of Education, Culture, Sports, Science and Technology of Japan.

\section{REFERENCES}

1. Huber R, Stetter KO. Discovery of hyperthermophilic microorganisms. Method Enzymol. 2001;330:11-24.

2. Sako Y, Nomura N, Uchida A, Ishida Y, Morii H, Koga Y, Hoaki T, Maruyama T. Aeropyrum pernix gen. nov., sp. nov., a novel aerobic hyperthermophilic archaeon growing at temperatures up to $100^{\circ} \mathrm{C}$. Int. J. Syst. Bacteriol. 1996; 46: 1070-1077.

3. Sako Y, Nomura N. Genus Aeropyrum. In: Garrity GM et al.(eds) Bergey's manual of systematic bacteriology, 2nd edition, volume 1. Springer-Verlag, New York. 2001; 183-184.

4. Kawarabayasi $Y$ et al. Complete genome sequence of an aerobic hyper-thermophilic crenarchaeon, Aeropyrum pernix K1. DNA Res. 1999; 6: 83-101.

5. Cann IKO, Ishino S, Nomura N, Sako Y, Ishino Y, Two family B DNA polymerases from Aeropyrum pernix, an aerobic hyperthermophilic crenarchaeote. J. Bacteriol. 1999; 181: 59845992.

6. Sako Y, Chavez Crooker P, Ishida Y. An extremely beatstable extracellular proteinase (aeropyrolysin) from the hyperthermophilic archaeon Aeropyrum pernix K1. FEBS Lett. 1997; 415: 329-334.

7. Chavez Crooker P, Sako Y, Uchida A. Purification and characterization of an intracellular heat-stable proteinase from the marine hyperthermophilic archaeon Aeropyrum pernix K1. Extremophiles 1999; 3: 3-9.

8. Nomura N, Sako Y, Uchida A. Molecular characterization and postsplicing fate of three introns within the single rRNA operon of the hyperthermophilic archaeon Aeropyrum pernix K1. J. Bacteriol. 1998; 180: 36353643.

9. Belfort M, Roberts RJ. Homing endonucleases: keeping the house in order. Nucleic Acids Res. 1997; 25: 33793388.

10. Dujon, B. Group I introns as mobile genetic elements: facts and mechanistic speculation -a review. Gene 1989; 82: 91-114. 